\title{
Comparison of Consumer Perceptions of the Marketing Mix at the Indomaret Minimarket with the Alfamart Minimarket in Pagar Alam City
}

\section{Perbandingan Persepsi Konsumen Terhadap Bauran Pemasaran Pada Minimarket Indomaret Dengan Minimarket Alfamart Di Kota Pagar Alam}

\author{
Baheramsyah ${ }^{1)}$; Novriansyah ${ }^{2)}$ \\ 1,2) Program Study Management Faculty of Economic and Bussiness, Institut Teknologi dan Bisnis Lembah Dempo \\ Email: ${ }^{1)}$ Baherampga11@gmail.com; ${ }^{2)}$ novriansyah@lembahdempo.ac.id
}

\begin{abstract}
How to Cite :
Baheramsyah., Novriansyah. (2021). Comparison of Consumer Perceptions of the Marketing Mix at the Indomaret Minimarket with the Alfamart Minimarket in Pagar Alam City. EMAK: Jurnal Ekonomi Manajemen Akuntansi Dan Keuangan, 2(4). DOI: https://doi.org/10.53697/emak.v2i3
\end{abstract}

\begin{abstract}
ARTICLE HISTORY
Received [30 September 2021]

Revised [05 October 2021]

Accepted [15 October 2021]

KEYWORDS

Price, Product, Promotion, Place

This

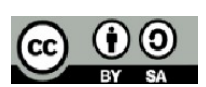

\section{ABSTRAK}

Penelitian ini menguji rasio persepsi konsumen terhadap Harga, Produk, Promosi dan Tempat pada Minimarket Indomaret dan Minimarket Alfamart di Kota Pagar Alam. Penelitian ini merupakan penelitian Komparatif. Untuk menentukan responden menggunakan accidential sampling, sedangkan jumlah responden dalam penelitian ini sebanyak 100 responden. Metode pengumpulan data yang digunakan terdiri dari metode : Angket dan dokumentasi. Sedangkan untuk mengetahui hubungan antara variabel penulis menggunakan metode perhitungan Validitas, Realibilitas, dan sampel responden dengan alat analisis spss 16.0. Hasil penelitian menunjukkan bahwa selisih Harga, Produk, Promosi dan Tempat oleh responden terhadap Minimarket Indomaret dengan Minimarket Alfamart Di Kota Pagar Alam.

\section{ABSTRACT}

This study examines the ratio of consumer perceptions of Price, Product, Promotion and Place at the Indomaret Minimarket and Alfamart Minimarket in Pagar Alam City. This research is a comparative research. To determine the respondents using accidential sampling, while the number of respondents in this study were 100 respondents. The data collection method used consists of the following methods: Questionnaire and documentation. Meanwhile, to find out the relationship between the variables the author uses the method of calculating validity, reliability, and the sample of respondents using the SPSS 16.0 analysis tool. The results showed that the difference in price, product, promotion and place by respondents to the Indomaret Minimarket and Alfamart Minimarket in Pagar Alam..
\end{abstract}

\section{PENDAHULUAN}

Perkembangan dunia saat ini berjalan dengan pesat, yang menciptakan suatu persaingan yang semakin ketat pada berbagai sektor industri. Hal ini yang menuntut produsen untuk lebih peka, kritis dan kreaktif terhadap perubahan yang ada, baik politik, sosial, budaya, dan ekonomi. Di era globalisasi sekarang ini kegiatan bisnis khususnya pemasaran dari waktu ke waktu semakin

544 | Baheramsyah, Novriansyah; Comparison of Consumer Perceptions of... 
meningkat, banyak sekali perusahaan yang berusaha memenangkan persaingan dengan cara memanfaatkan peluang bisnis yang ada dan berusaha menerapkan strategi pemasaran yang tepat dalam rangka menguasai pasar. Penguasaan pasar merupakan salah satu dari kegiatan-kegiatan pokok yang di lakukan oleh perusahaan untuk mempertahankan hidupnya, berkembang dan mendapatkan laba semaksimal mungkin.

Syarat yang harus dipenuhi oleh suatu perusahaan agar dapat berhasil dalam persaingan adalah berusaha mencapai tujuan untuk menciptkan dan mempertahankan pelanggan dengan membuat citra yang baik di mata pelanggan itu sendiri yang nantinya akan menimbulkan loyalitas yang berkelanjutan. Hal tersebut bisa dicapai oleh suatu perusahaan melalui upaya menghasilkan dan menyampaikan barang serta jasa yang diinginkan konsumen.

Perkembangan kebutuhan masyarakat dan perubahan gaya hidup, terutama dikota-kota besar khususnya di kota pagar alam, mengakibatkan perubahan perilaku berbelanja. Saat ini masyarakat lebih mengutamakan unsur kenyamanan, kepraktisan, kebersihan, dan keamanan dalam berbelanja. Oleh karena itu, sekarang ini masyarakat lebih senang berbelanja di ritel modern seperti di Minimarket dari pada berbelanja di pasar.

Perubahan perilaku masyarakat dalam berbelanja yang diikuti oleh kemampuan daya beli, telah menjadikan bisnis eceran menjadikan potensi bisnis yang sangat menarik bagi investor. Seperti sekarang ini, bisnis ritel di indonesia sangat ketat, terbukti dengan menjamurnya ritel-ritel yang tersebar luas di seluruh pelosok indonesia. Hampir disetiap wilayah indonesia kita dapat dengan mudah menemukan ritel-ritel yang berada disekitar kita seperti ritel modern. Faktor penarik pelanggan untuk berbelanja di ritel modern seperti Minimarket adalah ketersediaan barang dan harga yang terjangkau. Peritel Minimarket harus mampu menerapkan strategi dalam menentukan keberagaman barang dagangan yang akan ditawarkan pada pelanggan. Indomaret dengan Minimarket Alfamart akan di Persepsikan berbeda oleh masing-masing konsumen.

Secara umum persepsi konsumen terhadap pasar modern sangat positif karena pada saat seseorang mendengar istilah"Pasar Modern" maka orang-orang memiliki persepsi bahwa pasar yang dimaksud berada dalam bangunan megah, fasilitas memadai, nyaman. Pada umumnya hargaharga barang yang ditawarkan akan lebih mahal namun kualitasnya terjamin. Hal tersebut didukung dengan peraturan Presiden RI No.12 Tahun 2007 tentang Penataan dan Pembinaan Pasar Tradisional, Pusat Perbelanjaan dan Toko Modern (dalam Eka A,2014), mendefinisikan, "Pasar modern atau toko modern adalah toko dengan sistem pelayanan mandiri, menjual berbagai jenis barang secara eceran yang berbentuk Minimarket, supermarket, departement store, hypermarket ataupun grosir".

Dari pengertian tersebut nampak bahwa perusahaan menjajaki apa yang diminta dan dibutuhkan oleh konsumen dan kemudian berusaha mengembangkan produk yang akan memuaskan konsumen sehingga menjadikan konsumen memiliki banyak alternatif pilihan produk sebelum mengambil keputusan untuk membeli suatu produk yang ditawarkan.

Dalam perkembangan selanjutnya, konsumen menjadi faktor kunci penentu atas keberhasilan atau kegagalan suatu perusahaan di dalam memasarkan produknya. Perusahaan harus mampu mengenali secara dini apa yang menjadi kebutuhan dan harapan konsumen saat ini maupun masa yang akan datang. Disinilah dibutuhkan seorang manajer pemasaran yang mempunyai pengetahuan seks baik untuk mengikuti perubahan yang terus-menerus ini, serta untuk merancang bauran pemasaran yang tepat.

Banyak faktor yang mempengaruhi perilaku konsumen dalam keputusan pembelian barang dan jasa. Mempelajari dan menganalisa perilaku konsumen dalam keputusan pembelian adalah hal yang penting, sebab dengan pengetahuan dasar yang baik mengenai perilaku konsumen akan dapat memberikan masukan yang berarti bagi perencanaan Bauran Pemasaran.

Sejak pemerintah mengeluarkan kebijakan waralaba tahun 1997 yang mengakibatkan industri retail tumbuh dengan pesat di Indonesia. Perkembangan Minimarket tersebut tidak terlepas dari konsep yang ditawarkan oleh para pelaku usaha dalam mendekati pelanggannya. Terdapat dua Minimarket yang terus berkibar dan saling bersaing di pasar retail yaitu Minimarket 
Indomaret dan Minimarket Alfamart. Keberadaan keduanya semakin hari semakin menjamur dan terus menguasai perdagangan ritel khususnya ritel modern.

Berdasarkan pemberitaan bisnis.com hingga mei 2019 jumlah seluruh gerai Minimarket Indomaret sudah mencapai 16.900 gerai dan jumlah seluruh gerai Minimarket Alfamart sudah mencapai 13.679 gerai. Penguasaan pangsa pasar sebesar itu menempatkan Minimarket Alfamart pada posisi nomor dua setelah Minimarket Indomaret. Di kota pagar Alam sendiri, Minimarket berbendera Indomaret sudah memiliki 10 gerai, sedangkan Alfamart sudah memiliki 7 gerai. Dengan banyaknya jumlah gerai kedua perusahaan tersebut maka akan mengakibatkan persaingan yang sangat ketat dalam memperebutkan pelanggan agar mau membeli produk-produk yang mereka jual.

Usaha-usaha yang dapat ditempuh dalam hal menarik pelanggannya adalah dengan memperbaiki atribut-atribut yang menempel pada suatu produk atau toko, atribut yang menyolok atau determinan baisanya masuk dari kategori berikut ini : (1) lokasi, (2) sifat dan kualitas pengamanan, (3) harga, (4) iklan dan promosi, (5) personel penjualan, (6) atribut fisik toko, (7) sifat pelanggan toko, (8) atmosfer toko dan (9) pelayanan dan kepuasan setelah transaksi.

Secara teoritis keputusan pembelian yang dilakukan konsumen terhadap barang yang di tawarkan sangat di pengaruhi oleh harga, produk, pelayanan, lokasi perusahaan atau toko. Namun kenyataannya bahwa meski minimarket memiliki karakteristik dan strategi yang hampir sama satu dengan yang lainnya, kenyataannya dapat memiliki hasil penjualan yang berbeda. Seperti, Minimarket Indomaret dan Minimarket Alfamart yang biasanya berdampingan.

\section{LANDASAN TEORI}

\section{Pemasaran}

Pemasaran adalah salah satu kegiatan pokok yang perlu dilakukan oleh perusahaan baik itu perusahaan barang atau jasa dalam rangka mencapai tujuan yaitu untuk mempertahankan kelangsungan hidup usahanya, untuk mendapatkan laba dan untuk berkembang. Hal tersebut disebabkan karena pemasaran merupakan salah satu kegiatan perusahaan, di mana secara langsung berhubungan dengan konsumen. Maka kegiatan pemasaran dapat diartikan sebagai kegiatan manusia yang berlangsung dalam kaitannya dengan pasar.

American Marketing Association (AMA) mendefinisikan pemasaran adalah suatu fungsi organisasi dan serangkaian proses untuk menciptakan, mengkomunikasikan, dan memberikan nilai kepada pelanggan dan untuk mengelola hubungan pelanggan dengan cara yang menguntungkan organisasi dan pemangku kepentingannya (kotler, 2016:5).

\section{Bauran Pemasaran}

Dalam pemasaran terdapat strategi yang disebut bauran pemasaran (Marketing Mix) yang mempunyai peranan penting dalam mempengaruhi konsumen untuk membeli produk atau jasa yang ditawarkan perusahaan ke pasar. Berikut ini adalah pengertian bauran pemasaran (marketing mix) menurut para ahli :

Menurut (Sofjan Assauri:2013) dalam bukunya Manajemen Pemasaran dan Pemasaran Jasa, menjelaskan bauran pemasaran adalah sebagai berikut :

"Marketing mix adalah kombinasi variabel atau kegiatan yang merupakan inti dari sistem pemasaran, variabel mana dapat dikendalikan oleh pemasaran untuk mempengaruhi reaksi para pembeli atau konsumen"

Adapun pengertian dari masing-masing bauran pemasaran adalah:

\section{Product (Produk).}

Menurut (kotler, 2000:428) merupakan "segala sesuatu yang dapat ditawarkan produsen untuk diperhatikan, diminta, dicari, dibeli, digunakan atau dikonsumsi pasar sebagai pemenuhan kebutuhan atau keinginan pasar yang bersangkutan". Produk disini bisa berupa apa saja (baik yang 
berwujud fisik maupun tidak) yang dapat ditawarkan kepada pelanggan potensial untuk.memenuhi kebutuhan dan keinginan tertentu. Produk merupakan semua yang ditawarkan ke pasar untuk diperhatikan, diperoleh dan digunakan atau dikonsumsi untuk dapat memenuhi kebutuhan dan keinginan yang berupa fisik, jasa, orang, organisasi dan ide.

Dari definisi diatas dapat disimpulakan bahwa produk adalah segala sesuatu yang ditawarakan oleh seseorang atau organisasi yang mempunyai manfaat, yang tujuannya untuk memuaskan keinginan dan kebutuhan konsumen. Produk yanag ditawarkan oleh perusahaan hendaknya adala sebuah produk yang menarik,mempunyai penampilan bentuk fisik yang bagus dan yang lebih dikenal, mudah diucapkan, dan diingat.

\section{Price (Harga)}

Dalam bauran pemasaran (marketing mix) harga merupakan faktor penting dalam menentukan kebijakan strategis dan taktis karena harga menentukan pendapatan dari suatu usaha/bisnis.

Harga menggambarkan besarnya rupiah yang harus dikeluarkan seorang konsumen untuk memperoleh satu buah produk. Definisi harga adalah sejumlah uang yang dibebankan untuk sebuah produk atau jasa. Secara lebih luas, harga merupakan unsur yang paling sensitif ditengah masyarakat kalangan ekonomi menengah kebawah, sebaik apapun pelayanan yang diberikan oleh sebuah produk, baik itu atribut yang terdapat dalam produk tersebut maupun atribut tambahan jika harga yang ditawarkan sangat tinggi tentunya tidak akan mendapatkan respon yang baik dari para calon pelanggan.

\section{Promotion ( promosi)}

Promosi merupakan salah satu faktor penentu keberhasilan suatu program pemasaran (Ratih Hurriyati, 2016:57). Promosi adalah upaya untuk memberitahukan atau menawarkan produk atau jasa dengan tujuan menarik konsumen untuk membeli atau mengkonsumsinya. Dengan adanya promosi, produsen atau distributor mengharapkan kenaikan angka penjualan.

\section{Place ( Tempat/Saluran Distribusi)}

Tempat adalah gabungan antara lokasi dan distribusi yang berhubungan dengan cara penyampaian barang melalui lokasi yang strategis (Ziethaml), Kestrategisan suatu tempat berkaitan dengan lokasi.

Lokasi adalah faktor penting dalam bauran pemasaran ritel ( ritel marketing mix), pada lokasi yang tepat, sebuah gerai lainnya yang berlokasi kurang strategis, meskipun keduanya menjual produk yang sama, oleh pramuniaga yang sama banyak dan terampil. Dengan kata lain, lokasi adalah faktor utama yang dipertimbangkan oleh konsumen.

Pemilihan lokasi toko atau gerai pada umumnya berkaitan dengan upaya untuk memudahkan konsumen untuk memperoleh produk atau jasa yang dibutuhkannya. Dalam menentukan lokasi, suatu pusat perbelanjaan harus mempertimbangkan pilihan lokasi atau tempat agar konsumen lebih tertarik.

\section{Minimarket}

Minimarket adalah toko swalayan yang hanya memiliki satu atau dua mesin register (http// www.sinarharapan.co.id). Sedang menurut ( Hendri ma'aruf, 2005:76) yang di sebut minimarket biasanya luas ruanganya adalah antar $50 \mathrm{~m}^{2}$ sampai $200 \mathrm{~m}^{2}$ serta berada pada lokasi yang mudah dijangkau konsumen.

Minimarket mengisi kebutuhan masyarakat akan warung yang berformat modern. dengan mini market, belanja sedikit di tempat yang dekat dan nyaman terpenuhi, perilaku konsumen yang menyukai tempat belanja bersih, sejuk, dan tertata rapi membuat minimarket menjadi lebih unggul dari warung dan toko. 
Minimarket yang masuk dalam kelompok seperti Indomeret dan Alfamart baik yang dimiliki perusahaan atau yang waralaba atau hanya operasional saja tergolong sebagai chain store yaitu toko atau gerai yang terhimpun di bawah satu nama dengan sistem yang sama termasuk dalam kegiatan pemasarannya, istilah lain dari chain store adalah multiple store.

Perusahaan yang pertama kali menggunakan format minimarket sebagai strategi bisnis di Indonesia adalah PT. Indomarco Prismatama yang pada tahun 1977 mendirikan minimarketnya yang pertama.

Dalam memilih toko / Minimarket konsumen memiliki kriteria evaluasi diantaranya adalah faktor kenyamanan, pelayanan, kelengkapan produk, dan lain sebagainya. Hal tersebut menjadikan faktor yang sangat penting dan harus diperhatikan produsen karena akan menjadi bahan perbandingan bagi konsumen untuk memilih toko mana yang akan didatangi konsumen ( James $F$ engel ), dalam membandingkan minimarket mana yang akan dikunjungi konsumen akan mempertimbangkan beberapa hal berikut diantaranya :

1. Konsumen membandingkan minimarket

Minimarket mana yang akan memberikan harga yang lebih murah meski pelayanan kurang memuaskan atau ada juga konsumen yang cenderung memilih pelayanan yang memuaskan meski harga yang ditawarkan lebih mahal.

2. Kelengkapan produk

Konsumen dalam memilih minimarket mana yang akan di kunjungi dengan mempertimbangkan lengkap atau tidaknya produk yang di jual pada minimarket itu, jika ada minimarket yang lebih lengkap meskipun jarak yang ditempuh agak jauh maka konsumen akan mengunjungi minimarket yang lebih lengkap produknya.

3. Promosi

Konsumen cenderung memilih minimarket mana yang menginformasikan produknya lebih baik melalui iklan yang menarik, namun ada juga konsumen yang tidak memetingkan promosi yang menarik untuk mendatangi suatu minimarket yang terpenting adalah pelayanan yang memuaskan.

4. Tempat / Lokasi

Konsumen mementingkan jarak minimarket manakah yang paling dekat dari tempat tinggal untuk efisiensi waktu, namun ada juga konsumen yang lebih mempertimbangkan tempat parkir yang nyaman meski jarak yang ditempuh lebih jauh dari tempat tinggal. Berdasarkan evaluasi di atas maka, penelitian ini mengangkat tentang perbandingan persepsi konsumen terhadap bauran pemasaran pada Minimarket Indomaret dengan Minimarket Alfamart di Jl. Kombes $\mathrm{H}$. Umar Kel. Bangun Jaya Kec. Pagar Alam Utara kota Pagar Alam yang memiliki letak yang tidak berjauhan sehingga dapat di gambarkan dibawah ini :

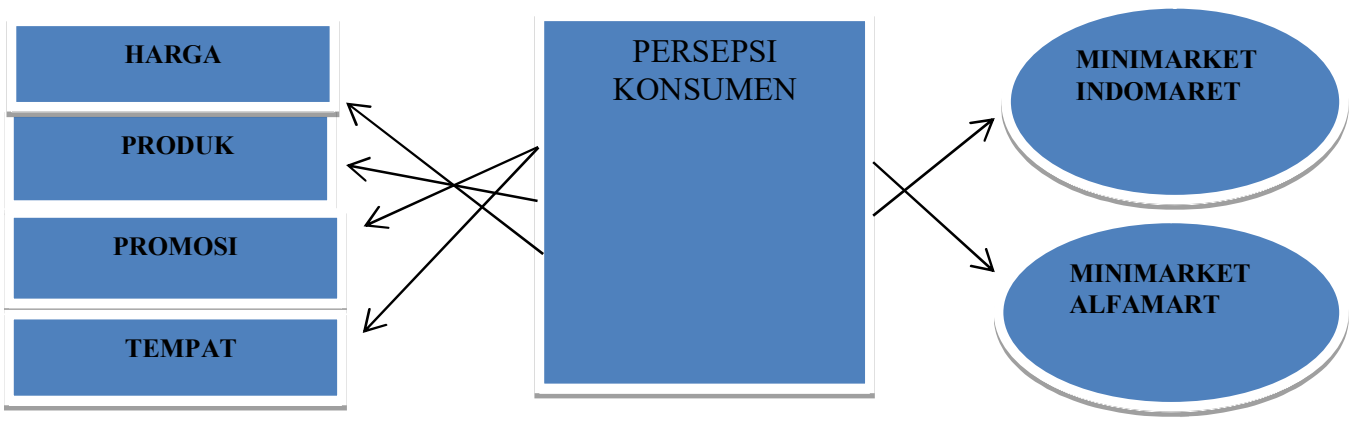

Sumber: diolah oleh penulis

Gambar 1. Kerangka Konseptual Penelitian

548 | Baheramsyah, Novriansyah; Comparison of Consumer Perceptions of... 


\section{METODE PENELITIAN}

\section{Metode Analisis}

Jenis penelitian ini adalah penelitian komparatif, merupakan suatu rumusan masalah penelitian yang membandingkan keberadaan satu variabel atau lebih pada dua atau lebih sampel yang berbeda, atau pada waktu yang berbeda. Menurut (Sugianto:2011) komparatif adalah suatu penelitian yang dilakukan untuk menggambarkan sekema hubungan dan pengaruh dari dua atau lebih fakta-fakta dan sifat-sifat obyek yang diteliti.

Penelitian ini ditujukan untuk menentukan penyebab atau alasan adanya perbedaan perilaku atau status kelompok individu. Studi kausal komparatif ini merupakan tindak lanjut dari studi korelasional. Jika korelasi menggambarkan derajat obyek yang diteliti, maka studi kausal komparatif menggambarkan sedemikian rupa hubungan sebab akibat. atau obyek itu. Dalam penelitian ini yang akan dijadikan populasi adalah konsumen pada Minimarket Indomaret dan konsumen Minimarket Alfamart.

\section{Sampel Dan Teknik Pengambilan Sampel}

Sampel adalah bagian dari jumlah dan kareteristik yang dimiliki oleh populasi tersebut (Sugiyono, 2017,:81). Untuk sampel yang diambil dari populasi harus betul-betul representative (mewakili). Dalam menentukan jumlah sampel dihitung berdasarkan rumus William g. cochran, sebagai berikut :

$n=\begin{gathered}z^{2} p q \\ e^{2}\end{gathered}$

Keterangan :

n: Jumlah Sampel Yang Diperlukan

z: 1,96 ( 1,96 adalah nilai kurve normal untuk simpangan 5\% )

p: Peluang Benar (50\%)

q: Peluang Salah (50\%)

e: Tingkat Kesalahan 5\%

berdasarkan rumus tersebut, maka diperoleh sampel pada penelitian ini yaitu perhitungan berikut : $n=\frac{z^{2} p q}{\mathrm{e}^{2}} n=\frac{1,96^{2}(0,5)(0,5)}{0,0,5^{2}} n=385$ orang

Dalam hal ini, mengingat populasi tidak diketahui sehingga peneliti memutuskan bahwa penarikan sampel dilakukan dengan cara accidential sampling ( sampling secara kebetulan ) yaitu siapa saja yang secara kebetulan bertemu dengan peneliti yang dijumpai di tempat tertentu, bila di pandang konsumen yang kebetulan ditemui itu cocok sebagai sumber data

(sugiyono,2017:85). Dengan alasan keterbatasan waktu, maka dalam mengambil sampel penelitian sebesar 100 responden. Dimana menurut (Sugiyono, 2017:91) ukuran yang layak untuk penelitian adalah antara 30 sampai dengan 500 responden.

Syarat-syarat yang harus dipenuhi responden di dalam penelitian ini, yang menggunakan metode accidential sampling adalah :

Usia responden dalam penelitian ini adalah $\geq 17$ tahun, dimana pada usia ini diasumsikan responden telah mampu dan mengerti serta dapat menanggapi masing-masing pertanyaan dalam kuesioner penelitian dengan baik.

Responden pernah berbelanja minimal 2 kali di Minimarket Indomaret dan 2 kali berbelanja di Minimarket Alfamart dengan alasan para konsumen yang pernah berbelanja di Minimarket Indomaret maupun Minimarket Alfamart mampu menginterpretasikan keadaan Minimarket tersebut dengan tepat sehingga mampu memahami terhadap maksud dari kuesioner yang diberikan. 


\section{HASIL DAN PEMBAHASAN}

\section{Hasil dan Pembahasan Uji Validitas}

Pengujian ini dimaksudkan untuk mengetahui seberapa besar ketepatan dan kecermatan suatu alat ukur dalam melakukan fungsi ukurnya. Uji validitas sebagai alat ukur dalam penelitian ini, yaitu menggunakan korelasi product moment person's, yaitu dengan cara mengkorelasikan tiap pertanyaan dengan skor total, kemudian hasil korelasi tersebut dibandingkan dengan angka kritis taraf signifikan 5\%. Adapun hasil pengujian validitas, sebagai berikut :

\section{Uji Validitas Quesioner Minimarket Alfamart}

Di bawah ini hasil uji validitas pernyataan pada Minimarket Alfamart di Kota Pagar Alam :

Tabel 1. Hasil Uji Validitas Quesioner Minimarket Alfamart

\begin{tabular}{|c|c|c|c|}
\hline Pernyataan & Product Moment Pearson's ( $r$ Hitung) & $r$ Tabel & Keterangan \\
\hline X1.1 & 0,804 & $>0,197$ & Valid \\
\hline X2.2 & 0,913 & $>0,197$ & Valid \\
\hline X1.3 & 0,869 & $>0,197$ & Valid \\
\hline X2.1 & 0,639 & $>0,197$ & Valid \\
\hline X2.2 & 0,809 & $>0,197$ & Valid \\
\hline X2.3 & 0,858 & $>0,197$ & Valid \\
\hline X3.1 & 0,871 & $>0,197$ & Valid \\
\hline X3.3 & 0,882 & $>0,197$ & Valid \\
\hline X4.1 & 0,863 & $>0,197$ & Valid \\
\hline X4.2 & 0,658 & $>0,197$ & Valid \\
\hline X4.3 & 0,846 & $>0,197$ & Valid \\
\hline
\end{tabular}

Sumber: Data Diolah, 2021

Berdasarkan tabel 1. diketahui bahwa Konsumen Minimarket Alfamart masing-masing indikator (item) dalam pertanyaan yang digunakan mempunyai hasil nilai product moment pearson's ( $r$ Hitung) dengan nilai masing-masing lebih besar dari $r$ tabel yaitu >0,198 (lihat lampiran 6) dimana $r$ tabel di dapat dari N-3= r, 100 pertanyaan - $2=98$ sehingga $r$ tabel di dapat 0,197 (lihat lampiran 6), sehingga indikator (item) yang digunakan dalam variabel penelitian ini dapat dinyatakan layak dan dapat digunakan sebagai alat dalam pengumpulan data.

Uji Validitas Quesioner Minimarket Indomaret

Di bawah ini uji validitas pernyataan pada Minimarket Indomaret di Kota Pagar Alam : Tabel 2. Hasil Uji Validitas Quesioner Minimarket Indomaret

\begin{tabular}{|c|c|c|c|}
\hline Pertanyaan & Product Moment Pearson's (r Hitung) & r Tabel & Keterangan \\
\hline X1.1 & 0,835 & $>0,197$ & Valid \\
\hline X1.2 & 0,784 & $>0,197$ & Valid \\
\hline X1.3 & 0,706 & $>0,197$ & Valid \\
\hline X2.1 & 0,851 & $>0,197$ & Valid \\
\hline X2.2 & 0,856 & $>0,197$ & Valid \\
\hline X3.1 & 0,892 & $>0,197$ & Valid \\
\hline X3.2 & 0,849 & $>0,197$ & Valid \\
\hline X3.3 & 0,904 & $>0,197$ & Valid \\
\hline X4.1 & 0,836 & $>0,197$ & Valid \\
\hline X4.2 & 0,885 & $>0,197$ & Valid \\
\hline X4.3 & 0,845 & $>0,197$ & Valid \\
\hline
\end{tabular}

Sumber: Data Diolah, 2021

550 | Baheramsyah, Novriansyah; Comparison of Consumer Perceptions of... 
Berdasarkan tabel 2. pada uji validitas pertanyaan yang diberikan peneliti oleh konsumen Minimarket Indomaret diketahui bahwa masing-masing indikator (item) dalam pertanyaan yang diberikan mempunyai hasil nilai product moment pearson's ( $r$ Hitung) dengan nilai masing-masing lebih besar dari $r$ tabel yaitu $>0,197$ (lihat lampiran 6) dimana $r$ tabel di dapat dari $N-2=r, 100$ responden $-2=98$ sehingga $r$ tabel di dapat 0,197 (lihat lampiran 6), sehingga indikator (item) yang digunakan dalam variabel penelitian ini dapat dinyatakan layak dan dapat digunakan sebagai alat dalam pengumpulan data.

Uji Reliabilitas

Pengujian ini dilakukan untuk menunjukan sejauh mana suatu hasil pengukuran relatif konsisten. Suatu pertanyaan atau pernyataan yang baik adalah pertanyaan atau pernyataan yang jelas mudah di pahami dan memiliki interpretasi yang sama meskipun disampaikan kepada responden yang berbeda dan dengan waktu yang berlainan. Uji realibitas menggunakan cronbach's alpha. Suatu instrument dikatakan reliabel apabila cronbac's alpha lebih besar dari 0,60 (Ghozali). Adapun hasil pengujian reliabilitas, sebagai berikut :

Uji Reliabilitas pada Minimarket Alfamart

Tabel 3. Hasil Uji Reliabilitas Hasil Pada Minimarket Alfamart

\begin{tabular}{|c|c|c|c|c|}
\hline Variabel & Cronbach's Alpha & Kriteria & N of Items & Keterangan \\
\hline Harga & 0,827 & $>0,6$ & 3 & Reliabel \\
\hline Produk & 0,651 & $>0,6$ & 3 & Reliabel \\
\hline Promosi & 0,837 & $>0,6$ & 3 & Reliabel \\
\hline Tempat & 0,694 & $>0,6$ & 3 & Reliabel \\
\hline
\end{tabular}

Sumber: Data Diolah, 2021

Berdasarkan tabel 3. hasil uji reliabilitas di atas menunjukkan bahwa data yang di peroleh bersifat reliabel karena angka Cronbach's Alpha lebih besar dari 0,6 ( $\alpha>0,6)$, yakni Harga $=0,827$, Produk $=$ 0,651, Promosi $=0,837$ dan Tempat $=0,694$, sehingga data yang di peroleh dapat dinyatakan reliabel dan dapat digunakan sebagai alat dalam pengumpulan data. Dimana pada masing-masing item memiliki nilai $>0,6$ sehingga data yang digunakan real sehingga layak digunakan untuk penelitian.

Uji Reliabilitas Minimarket Indomaret

Tabel 4. Hasil Uji Reliabilitas Hasil Pada Minimarket Indomaret

\begin{tabular}{|c|c|c|c|c|}
\hline Variabel & Cronbach's Alpha & Kriteria & N of Items & Keterangan \\
\hline Harga & 0,668 & $>0,6$ & 3 & Reliabel \\
\hline Produk & 0,833 & $>0,6$ & 3 & Reliabel \\
\hline Promosi & 0,829 & $>0,6$ & 3 & Reliabel \\
\hline Tempat & 0,818 & $>0,6$ & 3 & Reliabel \\
\hline
\end{tabular}

Sumber : Data Diolah, 2021

Berdasarkan tabel 4. hasil uji reliabilitas diatas menunjukkan bahwa data yang di peroleh bersifat reliabel karena angka Cronbach's Alphalebi besar dari 0,6 ( $a>0,6$ ), yakni Harga $=0,668$, Produk $=0,833$, Promosi $=0,829$ dan Tempat $=0,818$, sehingga data yang di peroleh dapat dinyatakan reliabel dan dapat digunakan sebagai alat dalam pengumpulan data.

\section{Uji Kesamaan Varian (F test)}

Sebelum dilakukan uji t test (Independent Sample t test) sebelumnya dilakukan uji kesamaan varian (homogenitas) dengan $\mathrm{F}$ test (Levene's Test), artinya jika varian sama, maka menggunakan Equal Variances Assumed (diasumsikan varian sama) dan jika varian berbeda menggunakan Equal Variancess Not Assumed (diasumsikan varian berbeda) (prayitno:2012). Adapun hasil uji kesamaan varian dengan $\mathrm{F}$ test ( Levence's Test ) : 
p-ISSN 2798-0499 e-ISSN 2798-0502

Tabel 5. Hasil Uji F test ( Levene's Test )

\begin{tabular}{|cl|c|c|c|}
\hline \multicolumn{2}{|c|}{ Levene's Test for Equality of Variances } & Kriteria & Equal Variances Assumed & $\begin{array}{c}\text { Equal Variances Not } \\
\text { Assumed }\end{array}$ \\
\hline Harga (X1) & Sig. & $>0,05$ & 0,132 & - \\
\hline Produk (X2) & Sig. & $>0,05$ & 0,615 & - \\
\hline Promosi (X3) & Sig. & $>0,05$ & 0,156 & - \\
\hline Tempat (X4) & Sig. & $>0,05$ & 0,640 & - \\
\hline
\end{tabular}

Sumber: Data Diolah, 2021

Berdasarkan tabel 5. hasil uji F test ( Levene's Test) diatas menunjukkan bahwa kriteria Ho diterima jika signifikan $>0,05$ dan Ho ditolak jika signifikasi $<0,05$ (Priyatno,2010). Hasil uji $F$ test diatas menunjukkan bahwa yang memiliki sifat varian sama (Equal variances Assumed), yaitu Harga, Produk, Promosi dan Tempat. Sedangkan yang memiliki sifat Varian sama berbeda (Equal Variances Not Assumed), yaitu tidak ada.

\section{Uji Dua Sampel Tidak Berhubungan (Independent Sample t test)}

Setelah melalui tahap uji kesamaan varian (homogenitas) dengan F test (Levene's Test), dapat diketahui variabel yang memiliki varian sama atau berbeda. Uji t test (Independent Sample $t$ test), dapat dilaksanakan dengan menggunakan asumsi dari hasil uji $\mathrm{F}$ tes (Levene's Test), dengan menggunakan Equal Variances Assumed dan Equal Variances Not Assumed. Independent Sample t test digunakan untuk mengetahui ada atau tidaknya perbedaan rata-rata dua kelompok sampel yang tidak berhubungan ( Santoso dalam Prayitno 2014).

Tabel 6. Hasil Uji T Test Independent Sample t test

\begin{tabular}{|c|c|c|c|c|c|c|c|}
\hline \multicolumn{2}{|c|}{$\begin{array}{l}\text { t-test for Equality of } \\
\text { Means }\end{array}$} & Group Statistics & Mean & $\begin{array}{c}\text { Mean } \\
\text { Difference }\end{array}$ & T & Sig. & Ket \\
\hline \multirow{8}{*}{$\begin{array}{c}\text { Equal } \\
\text { Variances } \\
\text { Assumed }\end{array}$} & \multirow[t]{2}{*}{ Harga (X1) } & Indomaret & 7,31 & \multirow[t]{2}{*}{$-2,590$} & \multirow{2}{*}{$-6,181$} & \multirow{2}{*}{0,000} & \multirow{2}{*}{ Signifikan } \\
\hline & & Alfamart & 9,90 & & & & \\
\hline & \multirow[t]{2}{*}{ Produk (X2) } & Indomaret & 10,54 & \multirow[t]{2}{*}{1,130} & \multirow[t]{2}{*}{2,660} & \multirow[t]{2}{*}{0,008} & \multirow[t]{2}{*}{ Signifikan } \\
\hline & & Alfamart & 9,41 & & & & \\
\hline & \multirow[t]{2}{*}{ Promosi (X3) } & Indomaret & 10,24 & \multirow[t]{2}{*}{1,070} & \multirow[t]{2}{*}{2,349} & \multirow[t]{2}{*}{0.020} & \multirow[t]{2}{*}{ Signifikan } \\
\hline & & Alfamart & 9,17 & & & & \\
\hline & \multirow[t]{2}{*}{ Tempat (X4) } & Indomaret & 10,06 & \multirow[t]{2}{*}{0,990} & \multirow[t]{2}{*}{2,311} & \multirow[t]{2}{*}{0,022} & \multirow[t]{2}{*}{ Signifikan } \\
\hline & & Alfamart & 9,07 & & & & \\
\hline
\end{tabular}

Sumber : Data Diolah, 2021

Berdasarkan tabel 4.8. pengujian ini dilakukan untuk mengetahui apakah ada atau tidak ada perbedaan antara rata-rata atribut determinan, yaitu Harga, Produk, Promosi, dan Tempat pada Minimarket Indomaret dengan Minimarket alfamart. Pengujian dilakukan dengan tingkat signifikan $5 \%$ ( tabel distribusi t dicari pada $a=5 \%: 2=2,5 \%$ uji dua sisi ) dan dengan derajat kebebasan (df) $\mathrm{n}-2$ atau 100-2 $=98$. Dengan pengujian dua sisi ( signifikan 0,025) hasil di peroleh untuk t tabel sebesar 1,98447. Berdasarkan hasil uji t, diperoleh hasil yang dapat dinyatakan sebagai berikut :

1. Variabel Harga (X1) memiliki nilai t-6,181 <1,98447 dan signifikasi 0,000<0,05, maka Ho ditolak, yang berarti ada perbedaan persepsi konsumen antara rata-rata harga pada Minimarket Indomaret dengan Minimarket Alfamart. Nilai t hitung negatif, berarti rata-rata harga pada Minimarket Alfamart lebih rendah dari pada Minimarket Indomaret. Dimana perbedaan rataratanya sebesar -2,590 sehingga Persepsi Konsumen terhadap Harga pada Minimarket Indomaret lebih mahal dibandingkan dengan harga pada Minimarket Alfamart.

2. Variabel produk $\left(\mathrm{X}_{2}\right)$ memiliki nilai t $2,660>1,98447$ dan signifikasi $0,008<0,05$, maka Ho ditolak, yang berarti ada perbedaan persepsi konsumen antara rata-rata produk pada

552 | Baheramsyah, Novriansyah; Comparison of Consumer Perceptions of... 
Minimarket Indomaret dengan Minimarket Alfamart. Nilai t hitung positif, berarti rata-rata Minimarket Indomaret lebih tinggi dari pada Minimarket Alfamart. Dimana perbedaan rataratanya sebesar 1,130. Sehingga Persepsi Konsumen terhadap Produk pada Minimarket Indomaret lebih banyak atau lengkap dibandingkan dengan minimarket Alfamart.

3. Variabel Promosi $\left(X_{3}\right)$ memiliki nilai t 2,349 $>1,98447$ dan signifikasi $0,020<0,05$, maka Ho ditolak, yang berarti ada perbedaan persepsi konsumen antara rata-rata promosi pada Minimarket Indomaret dengan Minimarket Alfamart. Nilai t hitung positif, berarti rata-rata Minimarket Indomaret lebih tinggi dari pada Minimarket Alfamart. Dimana perbedaan rataratanya sebesar 1,070. Sehingga Persepsi Konsumen terhadap Promosi yang di tawarkan oleh Minimarket Indomaret membuat konsumen tertarik dibandingkan dengan Minimarket Alfamart.

Variabel Tempat $\left(\mathrm{X}_{4}\right)$ memiliki nilai t 2,311 > 1,98447 dan signifikasi 0,022 < 0,05, maka Ho ditolak, yang berarti ada perbedaan persepsi konsumen antara rata-rata tempat pada minimarket Indomaret dengan minimarket Alfamart. Nilai t hitung positif, berarti rata-rata group 1 (Indomaret) lebih tinggi daripada group 2 (Alfamart). Dimana perbedaan rata-ratanya sebesar 0,990. Sehingga Persepsi Konsumen terhadap Tempat dari pada Minimarket Indomaret lebih baik dibandingkan dengan Minimarket Alfamart.

\section{Pembahasan Penelitian}

Hasil penelitian yang dilakukan pada konsumen Minimarket Indomaret dengan Minimarket Alfamart di Kota Pagar Alam, dengan menggunakan alat analisis compare mean - independent sample $t$ test, menunjukkan bahwa atribut determinan yang dijadikan perbandingan dalam penelitian, menunjukkan adanya perbedaan Persepsi Konsumen Minimarket Indomaret dan Minimarket Alfamart.

Hasil pengujian dari analisis compare mean - independent sample $t$ test menunjukkan bahwa ada perbedaan Persepsi Konsumen antara rata-rata Harga, Produk, Promosi dan Tempat pada Minimarket Indomaret dengan Minimarket Alfamart, dengan arti lain bahwa Persepsi Konsumen dalam menilai Harga, Produk, Promosi dan Tempat pada Minimarket Indomaret dan Minimarket Alfamart adalah berbeda. Harga, Produk, Promosi dan Tempat yang ada pada Minimarket Indomaret dan Minimarket Alfamart memang diasumsikan memiliki varian yang sama, tetapi Persepsi Konsumen dalam menilai rata-rata Harga, Produk, Promosi dan Tempat yang ada adalah berbeda.

Persepsi konsumen terhadap Harga produk pada Minimarket Alfamart lebih tinggi dari pada Minimarket Indomaret. Hal ini mengindikasikan bahwa harga produk dari Minimarket Alfamart lebih murah dari pada Minimarket Indomaret, harga produk yang ditawarkan Minimarket Alfamart lebih sesuai dari pada Minimarket indomaret, dan harga produk Minimarket Indomaret lebih terjangkau dari pada Minimarket Alfamart. Persepsi konsumen terhadap perbedaan harga ini dapat disebabkan pada Minimarket Indomaret harga yang ditawarkan masih relatif lebih mahal jika dibandingkan dengan Minimarket Alfamart, mean kedua pesaing ini relatif kecil hal ini disebabkan karena jika dibandingkan dengan toko-toko perancangan yang ada disekitar lokasi maka masih relatif lebih mahal kedua pesaing tersebut. Implikasinya, dibenak konsumen atribut harga merupakan hal yang membedakan antara Minimarket Alfamart dengan Minimarket Indomaret.

Persepsi konsumen terhadap produk, Minimarket Indomaret lebih tinggi dari pada minimarket Alfamart. Hal ini mengindikasikan bahwa produk yang ditawarkan Minimarket Indomaret lebih lengkap dibandingkan dengan Minimarket Alfamart, merek-merek produk yang di tawarkan Minimarket Indomaret lebih bermacam-macam dari pada Minimarket Alfamart, dan kualitas produk dari Minimarket Indomaret lebih baik dari pada Minimarket Alfamart. Persepsi konsumen terhadap perbedaan produk, dapat terjadi karena Minimarket Alfamart jumlah produk dan jenis produknya yang dijual kurang banyak.

Persepsi konsumen terhadap Promosi Minimarket Indomaret lebih tinggi dibandingkan Minimarket Alfamart. Hal ini mengindikasikan bahwa promosi dari Minimarket Alfamart kurang 
p-ISSN 2798-0499 e-ISSN 2798-0502

menarik dari pada Minimarket Indomaret, promosi Minimarket Alfamart jarang dilakukan dari pada Minimarket Indomaret, dan publisitas dari Minimarket Alfamart lebih kurang baik atau meyakinkan dari pada Minimarket Indomaret. Persepsi konsumen terhadap perbedaan promosi dapat terjadi karena Minimarket Indomaret biasanya melakukan promosi produknya dengan program permainan harga dan adanya tambahan bonus produk dalam pembelian untuk promosi dibentuk secara menarik. Implikasinya, dibenak konsumen atribut promosi merupakan hal yang membedakan antara Minimarket Indomaret dengan Minimarket Alfamart.

Persepsi konsumen terhadap Tempat Minimarket Indomaret lebih tinggi dari pada Minimarket Alfamart. Hal ini mengindikasikan bahwa tempat dari Minimarket Indomaret lebih strategis dan cukup mudah dijangkau dari pada Minimarket Alfamart dan akses jalan menuju Minimarket Indomaret lebih mudah dari pada minimarket Alfamart. Persepsi konsumen terhadap pebedaan tempat dapat terjadi karena Minimarket Indomaret biasanya memiliki tempat untuk dagangannya yang cukup mudah dilihat dan cukup luas dibandingkan dengan Minimarket Alfamart.implikasinya, dibenak konsumen atribut tempat merupakan hal yang membedakan antara Minimarket Indomaret dan Minimarket Alfamart

\section{KESIMPULAN DAN SARAN}

\section{Kesimpulan}

1. Berdasarkan hasil uji t test, diperoleh hasil yang dapat disimpulkan sebagai berikut :

a. Ada perbedaan persepsi konsumen terhadap harga antara Minimaket Indomaret dengan Minimarket alfamart. Group 1 (Indomaret) lebih rendah dari group 2 (Alfamart).

b. Ada perbedaan persepsi konsumen terhadap produk antara Minimarket Indomaret dengan Minimarket Alfamart. Group 1 (Indomaret) lebih tinggi dari pada group 2 (Alfamart).

c. Ada perbedaan persepsi konsumen terhadap promosi antara Minimarket Indomaret dengan Minimarket Alfamart. Group 1 (Indomaret) lebih tinggi dari pada group 2 (Alfamart).

d. Ada perbedaan persepsi konsumen terhadap tempat antara Minimarket Indomaret dengan Minimarket Alfamart. Group 1 (Indomaret) lebih tinggi dari pada group 2 (Alfamart).

2. Berdasarkan hasil uji t test, diketahui besarnya perbedaan rata-rata pada atribut determinan antara Minimarket Indomaret dan Minimarket Alfamart di Kota Pagar Alam sebagai berikut :

a. Pada atribut harga perbedaan rata-ratanya sebesar $-2,590$.

b. Pada atribut produk perbedaan rata-ratanya sebesar 1,130.

c. Pada atribut promosi perbedaan rata-ratanya sebesar 1,070.

d. Pada atribut tempat perbedaan rata-ratanya sebesar 0,990.

Saran

Pihak Minimarket Alfamart diharapkan mampu meningkatkan kelengkapan produk, promosi dan tempat yang ada, karena dengan meningkatkan produk yang akan dijual, promosi dan tempat yang lebih baik, diharapkan konsumen dapat memiliki persepsi yang lebih baik pada Minimarket Alfamart. Pada Minimarket Indomaret diharapkan mampu menurunkan harga yang ditawarkan untuk membenahi tingkat kesesuaian harga beli produk, sehingga diharapakan konsumen dapat memiliki persepsi yang lebih baik pada Minimarket Indomaret yang ada.

\section{DAFTAR PUSTAKA}

Hendri, Ma'ruf. 2010. Pemasaran Ritel. Jakarta : PT Gramedia Pustaka Utama.

Hurriyati Ratih, 2018. Bauran Pemasaran dan Loyalitas Konsumen. Bandung: Alfabeta,

Kotler Philip, Kevin Lane Keller, 2016. Manajemen Pemasaran. Jakarta: PT Gelora Aksara cv Pratama. Sugiyono,Prof.Dr.2013. Metode Penelitian Manajemen. Bandung : Penerbit Alfabeta Sugiyono, 2017, Metode PenelitianKuantitatif, Kualitatif dan R\&D,Alfabeta, Bandung Sugiyono, 2012, Metode Penelitian Bisnis,Cetakan Kesembilan, Penerbit CVAlpha Betha, Bandung Kotler, Philip dan Kevin Lane Keller. 2011. Manajemen Pemasaran. EdisiRevisi. Jakarta : PT. Indeks.

554 | Baheramsyah, Novriansyah; Comparison of Consumer Perceptions of... 